\title{
Induction of cell fate in the Drosophila retina: the bride of sevenless protein is predicted to contain a large extracellular domain and seven transmembrane segments
}

\author{
Anne C. Hart, ${ }^{1}$ Helmut Krämer, ${ }^{1}$ David L. Van Vactor, Jr., ${ }^{1}$ Mukund Paidhungat, and \\ S. Lawrence Zipursky \\ Department of Biological Chemistry, The School of Medicine and The Molecular Biology Institute, University of California, \\ Los Angeles, California 90024-1737 USA
}

Previous genetic mosaic studies established that expression of the Drosophila bride of sevenless (boss) gene is required in photoreceptor neuron $\mathbf{R 8}$ for the development of photoreceptor neuron $\mathbf{R} 7$. This led to the proposal that boss encodes or regulates an R7-specific inductive cue. We have identified the boss gene based on small deletions in mutant alleles and sequenced both cDNAs and corresponding genomic regions. One $P$ element and three X-ray-induced boss alleles show different deletions in the gene ranging in size from 2 to 23 bp, each causing frameshifts leading to premature termination of translation. The boss gene encodes a protein of 896 amino acids with a putative amino-terminal signal sequence, a large extracellular region of 498 amino acids, and seven potential transmembrane domains followed by a carboxy-terminal cytoplasmic tail of 115 amino acids. The putative membrane localization of the boss protein is consistent with a model in which direct interaction between the boss and sevenless proteins specifies $R 7$ cell fate. Another model in which the boss protein functions as a receptor is proposed based on its similarity to the $G$ protein-linked family of membrane receptors.

[Key Words: Drosophila; boss; retina; cell-cell interaction]

Received July 9, 1990; revised version accepted August 17, 1990.

Little is known about the mechanisms that establish the complex pattern of cell types found in the nervous system. In vertebrates, lineage marker experiments indicate that developing neurons rely largely on their environment rather than intrinsic programs for the specification of their final position and cellular fate (e.g., Turner and Cepko 1987). Defined precursor populations isolated from rat optic nerve (e.g., Raff et al. 1988) or neural crest (e.g., Anderson and Axel 1985) choose between alternative fates in vitro, depending on the presence of specific growth factors and hormones. Such studies have underscored the importance of understanding the precise temporal and spatial control of developmental cues. In Drosophila and Caenorhabditis elegans, a combination of classical and molecular genetics allows the manipulation of individual genes in vivo. In these organisms, developmental and genetic analyses have provided molecular insight into a variety of cellular interactions that control cell fate (for reviews, see Artavanis-Tsakonas 1988; Greenwald 1989|.

Among the different systems studied in Drosophila,

${ }^{1}$ These authors contributed equally to this work and are listed in alphabetical order. the compound eye is particularly well suited for analyzing determinative interactions at the single-cell level and the role of specific genes in regulating this process (for reviews, see Tomlinson 1988; Ready 1989; Rubin 1989; Banerjee and Zipursky 1990). The compound eye consists of 800 repeated units, or ommatidia. Each ommatidium contains a precise array of eight photoreceptor cells, R1-R8, surrounded by 14 additional cells that isolate the unit optically and synthesize the lens. Although a number of molecules involved in the assembly of the ommatidium have been identified, very little is currently known about the nature and regulation of the developmental cues that govern this process.

The proposal that inductive interactions are important in the establishment of Drosophila retinal cell fate is based largely on genetic mosaic analyses in which obligatory lineage relationships between different retinal cell types were not observed (Ready et al. 1976; Lawrence and Green 1979). Transplantation studies support the view that these interactions are local in nature (Lebovitz and Ready 1986). Based on electron microscopic analysis of the developing ommatidium (Tomlinson 1985) and subsequent studies using neuron-specific antibodies, Tomlinson and Ready (1987a) proposed 
a combinatorial model of R-cell determination in which the fate of an undifferentiated cell in each developing cluster is determined by its position and, hence, its interactions with a unique set of neighboring cells. After a cell has been determined, it participates in directing neighboring cells to assume distinct fates. Recent genetic mosaic analyses showing that bride of sevenless (boss; Reinke and Zipursky 1988) and rough (Tomlinson et al. 1988) act in a cell nonautonomous fashion provide evidence for inductive interactions between specific cells.

The development of the R7 neuron is of particular interest as several genes have been identified that are involved in the interpretation and the production of cues that specifically influence its development. Ommatidia in sevenless (sev; Harris et al. 1976) and boss (Reinke and Zipursky 1988) mutant eyes lack only the R7 neuron. In $s e v$, the precursor that would normally assume the R7 fate becomes a lens-secreting cone cell instead (Tomlinson and Ready 1986). Genetic mosaic studies established that the sev gene is required only in the R7 cell (Harris et al. 1976; Campos-Ortega et al. 1979; Tomlinson and Ready 1987b). Molecular studies revealed that the sev gene product is a membrane protein (Baneriee et al. 1987; Tomlinson et al. 1987) with a large extracellular domain and a carboxy-terminal, cytoplasmic tyrosine kinase domain (Hafen et al. 1987; Basler and Hafen 1988; Bowtell et al. 1988). These properties led to the proposal that the sev protein is a receptor for an inductive cue that specifically regulates R7 cell fate. The observation that boss is required in R8 for the development of only one of its neighbors, R7, suggests that boss either encodes this inductive cue or regulates its presentation (Reinke and Zipursky 1988). On the basis of the molecular analysis of the boss gene presented here, we propose that the boss protein plays a direct role in intercellular communication.

\section{Results}

Review of compound eye and photoreceptor $R 7$ development

The retinal primordium, the eye imaginal disc, is a packet of some 20 cells set aside as an invagination of the embryonic ectoderm (Garcia-Bellido and Merriam 1969). Pattern formation and neural differentiation do not commence until the beginning of the third instar of larval development. During the third instar, a wave of differentiation, marked by a groove in the disc epithelium called the morphogenetic furrow (MF), sweeps across the eye disc from posterior to anterior (Fig. 1A). Anterior to the MF, cells are unpatterned and undifferentiated, whereas immediately posterior to the MF, clusters of differentiating photoreceptor neurons (R1-R8) form in a highly stereotyped and sequential fashion (Ready et al. 1976; Tomlinson and Ready 1987a). Based on the expression of neuronal antigens recognized by an anti-HRP antibody and $\mathrm{mAb} 22 \mathrm{C} 10$, the central $\mathrm{R} 8$ cell was shown to differentiate first, followed by the pairwise differentiation of the surrounding cells R2 and R5, R3 and R4, R1 and R6 and, finally, R7. Each cell forms a unique set of cell contacts that have been speculated to play an important role in patterning (Tomlinson and Ready 1987a).

An electron microscopic analysis of photoreceptor cell R7 development has been carried out in both normal and sev mutant discs by Tomlinson and Ready (1986). In both mutant and wild type, the precursor to the R7 neuron assumes a position within the developing cluster abutting the R1, R8, and R6 cells. In the wild-type eye disc, as the $\mathrm{R} 7$ neuron begins to differentiate, its nucleus falls basally, whereas the nuclei of the precursors to the cone cells rise within the epithelium. However, in the sev mutant, the nucleus of the $\mathrm{R} 7$ precursor cell fails to fall within the disc epithelium and remains in an apical position. This mutant cell fails to express neuronal markers and will later give rise to a cone cell.

\section{The R7 neuron fails to develop in boss eye discs}

We have analyzed the development of the $\mathrm{R} 7$ cell in boss eye discs at the level of the light microscope using cell type-specific markers (W. Biggs et al., unpubl.) and cobalt sulfide staining. Ommatidial assembly in both $\mathrm{mu}-$ tant and wild-type discs is identical until the stage at which the R7 cell differentiates in the wild-type ommatidium, as visualized by the neuron-specific anti-elav antibody (see Materials and methods). In boss, only seven cells differentiate as neurons (Fig. 1C). In addition, the R7-specific marker XA12, which appears at an early stage of $\mathrm{R} 7$ cell differentiation, $\sim 12$ to 15 rows posterior to the MF, is not expressed in a boss background (Fig. 1B). Thus, in boss, the R7 precursor cell fails to differentiate into an $\mathrm{R} 7$ neuron.

The appearance of boss and sev discs is indistinguishable in preparations stained with anti-elav antibodies and for the expression of XA12. By observing different stages of ommatidial assembly, using cobalt sulfidestained preparations, the nucleus of the cell, which would normally adopt an R7 cell fate, appears to remain in an apical position in boss discs in a manner similar to that seen in sev discs (data not shown). This cell occupies the position of a cell that will later differentiate into the lens-secreting cone cell. Therefore, we propose that in the absence of a signal from R8 in boss mutants, the R7 precursor fails to develop as an R7 neuron and responds to a later cue regulating cone cell development.

Several lines of evidence indicate that the R8 cell is normal in boss, suggesting that the failure of $\mathrm{R} 7$ to develop is not a consequence of a general defect in R8 development. First, in the third instar disc, the R8 cell develops normally as assessed by staining with anti-elav antibody, cobalt sulfide, and the R8-specific markers BB02 (Fig. 1B) and LA24 (data not shown). Second, in the adult, R8 somal morphology viewed by electron microscopy (Reinke and Zipursky 1988) and the R8 axonal projections visualized at the level of the light microscope with mAb24B10 (Fuijta et al. 1982) are normal (R. Mestel, unpubl.). 


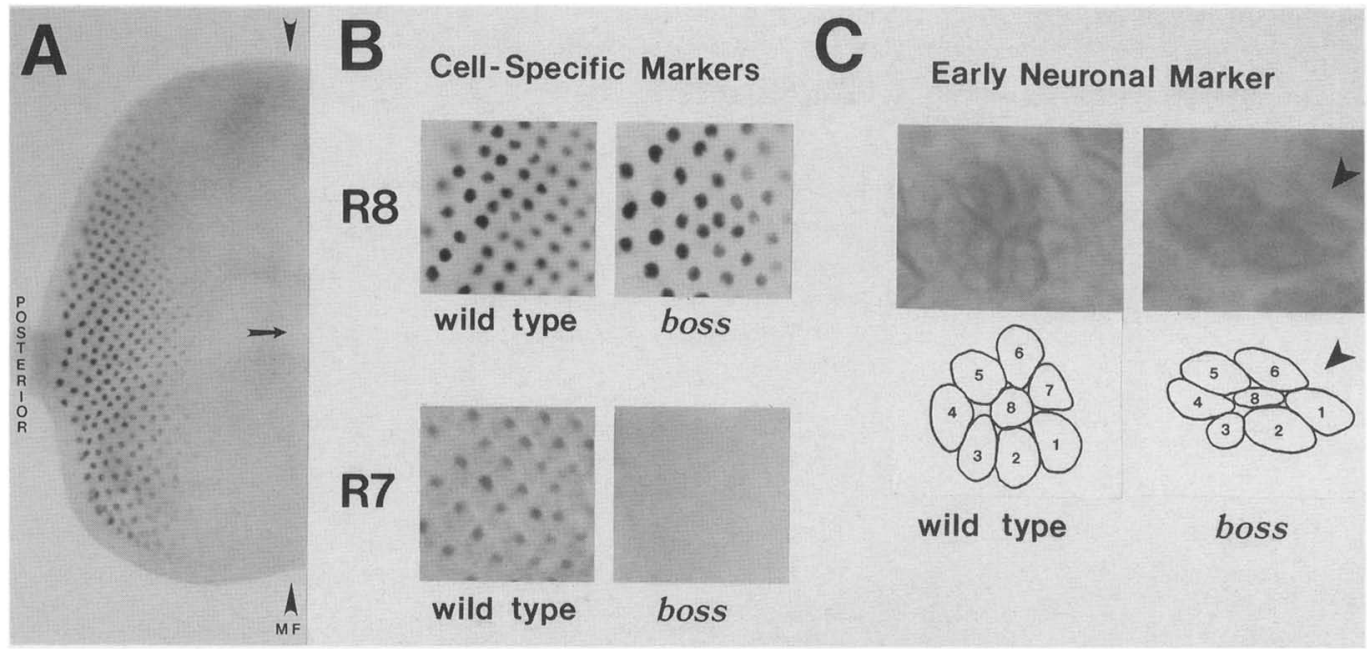

Figure 1. Neuronal development in boss imaginal discs visualized with cell-specific markers. (A) R8-specific marker expressed in the eye imaginal disc: The expression of the R8 marker BB02 is visualized in a whole-mount preparation of an eye imaginal disc. Pattern formation and cellular differentiation proceed as a wave of morphogenesis marked at its leading edge by the MF (see arrowheads). The MF moves from posterior to anterior, with the R8 cell being the first to differentiate just posterior to the MF (Tomlinson and Ready 1987a). Developing ommatidia in the posterior region of the disc are older than those anterior to them. BB02 expression in the R8 cell is observed first $\sim 10$ rows posterior to the MF. The arrow indicates the direction of movement of the MF. The distribution of the marker was visualized by using a second antibody conjugated to horseradish peroxidase (HRP) and development with 3,3'-diaminobenzidine. Magnification, $130 \times .(B)$ The expression of cell-specific markers in wild-type and boss discs: The R8-specific marker BB02 (top) is expressed in an identical manner in both wild-type and boss eye imaginal discs. In a wild-type disc, the R7 marker XA12 (bottom) is first observed $\sim 12$ to 15 rows posterior to the MF. In boss discs, XA12 does not stain. Discs were stained as described in Materials and methods. Magnification, $320 \times$ for all but BB02 in wild type, which is $260 \times$. (C) Staining of R-cell clusters with an early neuronal marker. Wild-type and boss discs were stained with affinity-purified antiserum to the Drosophila elav gene product, an early neuronal differentiation marker (Robinow et al. 1988), and a second antibody coupled to HRP. In contrast to $B$, staining was obtained by incubation with 3-amino-9-ethylcarbazole; this formed a reddish precipitate that preferentially outlined the neuronal nuclei (see Materials and methods). The clusters indicated as wild type and boss are 12 rows posterior to the MF. In a wild-type disc, eight neuronal nuclei are observed. In contrast, in boss only seven neuronal nuclei are observed /arrowhead marks position that would be occupied by the R7 nucleus|. In no case were more than seven neuronal nuclei observed in a boss ommatidium, as assessed by optical sectioning throughout the depth of the epithelium. A tracing of each cluster is shown beneath the stained preparation. Magnification, $800 \times$.

\section{Localization of the boss genes}

The isolation of the boss ${ }^{1}$ allele was described previously (Reinke and Zipursky 1988). An additional 18 noncomplementing alleles were generated by using $X$ rays, ethylmethane sulfonate (EMS), diepoxybutane, and P-M hybrid dysgenesis (see Table 1). All alleles are phenotypically identical to boss ${ }^{1}$, as assessed by the phototactic choice test and direct light microscopic observation of adult ommatidial structure using the pseudopupil method (Franceschini and Kirshfeld 1971a,b). The boss $^{1}$ allele was mapped by meiotic recombination to 90-91 map units on chromosome 3R (Reinke and Zipursky 1988), just proximal to Enhancer of split [E(spl)]. Deficiency mapping with boss (see Table 1) and E(spl) alleles allowed us to position the boss gene between cytological bands 96F5/7 through 96F11/14 (Reinke and Zipursky 1988). A genomic walk from the $E(s p l)$ region (Knust et al. 1987) was extended (see Fig. 2) and used for Southern analysis of boss and $E(\mathrm{spl})$ alleles by using restriction enzymes with 6-bp recognition sites. The $E(s p 1)^{B \times 21}$ deficiency (Preiss et al. 1988) complements boss $^{1}$ and establishes a distal limit on the extent of the boss gene. Southern blotting analysis and in situ hybridization to polytene chromosomes (data not shown) demonstrated the presence of a deficiency/translocation breakpoint in a $6.5-\mathrm{kb}$ EcoRI fragment in boss $^{3}$ (see Fig. 2).

Further evidence for the location of boss between the $E(s p l)^{B X 21}$ and $b_{0 s s^{3}}$ breakpoints came from meiotic recombination. A series of recombinant lines was generated between boss $^{1}$ and a P-element transposon inserted in $96 \mathrm{~F} 3 / 5$, which carried as markers the neomycin-resistance and $l a c Z$ genes (see Materials and methods). Recombination sites in lines carrying both boss ${ }^{1}$ and the transposon were mapped by using restriction fragmentlength polymorphisms. Eighty-seven recombinants were recovered, of which the most distal recombined at scattered sites within a $25-\mathrm{kb}$ region, proximal to $+7 \mathrm{~kb}$ on the genomic map (see Fig. 2). The most distal of the crossover events isolated between boss ${ }^{1}$ and the transposon mapped in, or proximal to, the $6.5-\mathrm{kb}$ genomic fragment, which contains the boss ${ }^{3}$ breakpoint. Thus, this recombination event established a proximal limit on the lesion in the boss ${ }^{1}$ allele. This evidence suggested that the boss gene lay between the breakpoint of 
Hart et al.

Table 1. Analysis of boss alleles

\begin{tabular}{|c|c|c|c|}
\hline Allele & Mutagen & Cytology & Molecular lesion \\
\hline 1 & $\mathrm{X}$ ray & normal & $\Delta 23 \mathrm{bp}$ \\
\hline 2 & $\mathrm{X}$ ray & normal & ND \\
\hline 3 & $\mathrm{X}$ ray & $\begin{array}{l}\operatorname{Tr}(2 / 3) 96 \mathrm{~F} 8 / 11-57 \mathrm{C} \\
\text { plus } \mathrm{Df} \mid 3 \mathrm{R} / 96 \mathrm{~F} 8 / 11-97 \mathrm{~B}\end{array}$ & see Fig. 2 \\
\hline 4 & $\mathrm{X}$ ray & normal & $\Delta 4 \mathbf{b p}$ \\
\hline 5 & $\mathrm{X}$ ray & $\begin{array}{l}\text { In(3)78D; 96E/F } \\
\text { plus Df(3R) } 96 \mathrm{E} / \mathrm{F}-97 \mathrm{E} / \mathrm{F}\end{array}$ & NA \\
\hline 6 & $\mathrm{X}$ ray & $\mathrm{Df}(3 \mathrm{R}) 96 \mathrm{~F} 3 / 5-97 \mathrm{C} / \mathrm{D}$ & NA \\
\hline 7 & $\mathrm{X}$ ray & normal & $\Delta 19$ bp \\
\hline 8 & $\mathrm{X}$ ray & $\operatorname{Tr}(2 / 3)^{\mathbf{a}}$ & complex ${ }^{a}$ \\
\hline 9 & EMS & $\mathrm{Df}(3 \mathrm{R}) 96 \mathrm{E} 6-97 \mathrm{~B} 4 / 6$ & NA \\
\hline 10 & EMS & normal & ND \\
\hline 11 & EMS & normal & ND \\
\hline 12 & EMS & normal & ND \\
\hline 13 & $\mathrm{P}-\mathrm{M}$ & $\mathrm{Df}(3 \mathrm{R}) 96 \mathrm{~F} 3 / 5-97 \mathrm{C} / \mathrm{D}$ & NA \\
\hline 14 & P-M & Df(3R) $96 F 3 / 5-97 C / D$ & NA \\
\hline 15 & P-M & $\operatorname{Df}(3 R) 96 F 3 / 5-11 / 12$ & NA \\
\hline 16 & $\mathrm{P}-\mathrm{M}$ & $\operatorname{Df}(3 R) 96 F 5 / 7-12 / 13$ & NA \\
\hline 17 & $\mathrm{P}-\mathrm{M}$ & normal & $\Delta \mathbf{2}$ bp \\
\hline 18 & DEB & ND & ND \\
\hline 19 & DEB & ND & ND \\
\hline
\end{tabular}

Alleles with abnormal cytology are homozygous lethal, whereas those with normal cytology in $96 \mathrm{~F}$ are viable over deficiencies for this region. Molecular lesions within the boss gene are described in the text. Alleles for which we have not detected a deficiency are designated ND (not determined). Alleles with cytologically visible deficiencies in the region are designated NA (not applicable), as they remove the entire boss gene. (EMS, DEB, and P-M) Ethylmethane sulfonate, diepoxybutane, and P-M hybrid dysgenesis, respectively. Boldface type indicates that the lesions are determined by sequence analysis. $\Delta$ designates a DNA deletion.

${ }^{a} b_{0 s s^{8}}$ is cytologically rearranged outside of $96 \mathrm{~F}$, and breakpoints have not been established. Although boss ${ }^{8}$ appears cytologically normal in the boss region, molecular analysis using high-resolution Southern blots suggests that a small insertion or rearrangement has occurred (data not shown).

$E(s p l)^{B \times 21}$ and the most distal recombination event, a physical distance of $\sim 45 \mathrm{~kb}$.

As a first step toward identifying the boss transcript, a reverse Northern blot analysis was completed for the entire walk (data not shown). Labeled cDNA probes were generated from head, body, and imaginal disc poly $(A)+$ RNA isolated from a wild-type strain and from imaginal disc poly $(A)^{+}$RNA extracted from a mutant, eyes absent (eya), which lacks the eye primordia in late third-instar disc (see Materials and methods). Five different regions of DNA showed hybridizations suggesting transcriptional activity in at least 10 genomic EcoRI fragments (data not shown). Both head and eye imaginal disc-specific hybridizations were observed. On the basis of these observations, genomic fragments were selected as probes for screening cDNA libraries and performing Northern blot analyses. We have identified seven transcription units within this $45 \cdot \mathrm{kb}$ region. A summary of the transcriptional activity in the poly $(\mathrm{A})^{+}$fraction of RNA isolated from imaginal discs and adult heads, as determined by Northern blot analysis, is presented in Figure 2.

\section{Identification of the boss gene and isolation of boss cDNAs}

The boss gene was identified through Southern blot analysis of boss mutant alleles by using restriction en- donucleases HaeIII, MspI, CfoI, and RsaI, which cut frequently within the $45 \mathrm{~kb}$ between the $b_{0 s s^{3}}$ and $E(s p l)^{B X 21}$ breakpoints. The only allele-specific changes in DNA structure found within the entire walk were localized to a 4-kb region (Figs. 2 and 3). Small deletions were detected in three X-ray alleles $\left(b o s s^{1}, b o s s^{4}\right.$, and boss $\left.^{7}\right)$ and in one P-element-induced allele (boss $\left.{ }^{17}\right)$. A complex pattern of changes within this small region was detected in another X-ray-induced allele, boss ${ }^{8}$ (data not shown). The DNA sequences deleted in the boss ${ }^{1}$, boss $^{4}$, boss $^{7}$, and boss $^{17}$ alleles are indicated in Figure 5 and are discussed below.

The small DNA deletions detected in the boss ${ }^{1}, b_{o s s^{4}}$, boss $^{7}$, and boss $^{17}$ alleles all mapped to a region encoding the $\mathrm{F}$ transcript (Fig. 2). By using a corresponding genomic fragment, a total of 19 individual clones were obtained from a screen of $1.2 \times 10^{6}$ phage from an amplified head cDNA library. The largest cDNA was $\sim 2.8 \mathrm{~kb}$ in length. Three of these cDNAs were analyzed in further detail (see Materials and methods). cDNA probes from this region hybridized to a single $3.2-\mathrm{kb}$ mRNA species found in imaginal disc and head tissue (Fig. 4). We estimate that the boss transcript is expressed at a level at least 100 -fold greater in poly $(A)+$ RNA isolated from head than in that isolated from total disc tissue. It is interesting to note that the $\operatorname{sev}$ transcript is also expressed highly in adult head tissue (Banerjee et al. 1987a; Hafen et al. 1987). The role of both boss and sev in the 


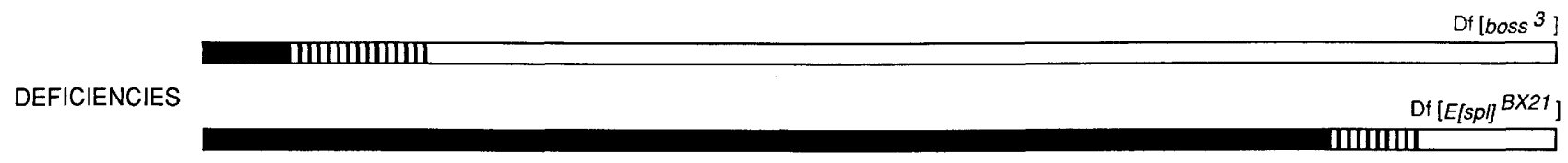

GENOMIC CLONES
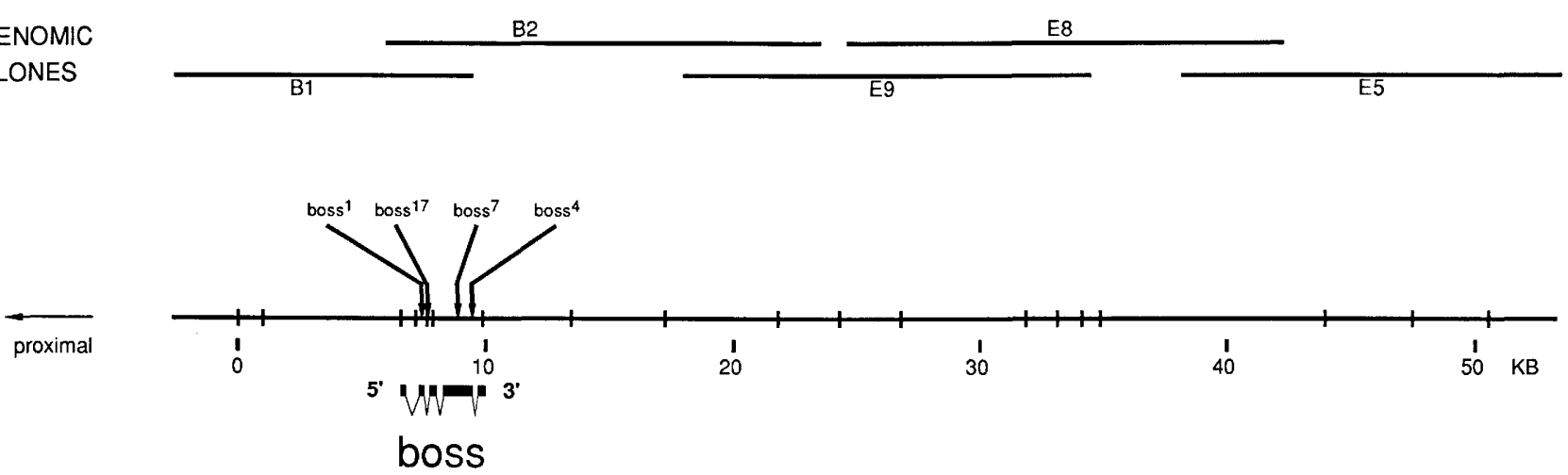

RNA
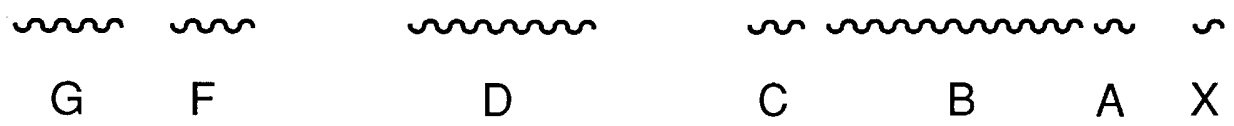

Figure 2. Molecular map of the bride of sevenless genomic region. The proximal breakpoints of the deletions in $b o s s^{3}$ and $E(s p l)^{B X 21}$ within $96 \mathrm{~F}$ are shown in relation to the EcoRI restriction map of the region containing the boss transcript. The centromere is to the left. The solid black bar indicates normal chromosomal DNA; the open bar indicates deleted DNA; broken lines indicate regions within which a break occurs. Lambda clones E5, E8, and E9 extend from the $E$ (spl) region, which is located distal to E5. The wavy lines indicate the transcriptional activity within the $45-\mathrm{kb}$ region between the two breakpoints as determined by Northern blotting. Each transcript is drawn approximately to scale, indicating the size of the major transcripts found in adult head and/or eye imaginal disc tissue poly $(\mathrm{A})^{+}$RNA. All RNAs are represented in both of these tissues except $\mathrm{A}$ and $\mathrm{X}$, which we were unable to detect in $10 \mu \mathrm{g}$ of poly $(\mathrm{A})^{+}$head mRNA. The boss gene is contained within clones $\mathrm{B} 1$ and $\mathrm{B} 2$, as determined by the molecular mapping of mutations. Arrows indicate the positions of small deletions observed in boss $^{1}$, boss $^{17}$, boss ${ }^{7}$, and boss ${ }^{4}$ (see Figs. 5 and 8). Below the EcoRI restriction map, the extent of the boss transcript is shown, displaying the five precisely mapped exons determined by comparison of cDNA and genomic sequences. An additional 50-bp 5' exon is predicted (not shown), based on RNase protection and primer extension analysis (Results; Fig. 6).

adult head has not been analyzed. Although altered levels of transcripts were observed in homozygous viable mutants $\left(\right.$ boss $^{12}$, boss $^{7}$, boss $^{4}$, and boss ${ }^{1}$ ) when compared to actin, none showed a detectable change in length (data not shown). Because the level of other transcripts in the walk also varied from one allele to another, the significance of the altered levels of the boss transcript is unclear.

Efforts to detect the boss mRNA in the eye disc by in situ hybridization using digoxigenin/dUTP-labeled probes were unsuccessful under conditions with which we obtained positive results for sev, chaoptic, decapentaplegic, and the $\mathrm{A}$ and $\mathrm{X}$ transcripts from the boss region (data not shown). Because the detection of the sev transcript appears to represent a lower limit to our level of detection using this technique, it is not surprising that we have not observed a signal with a boss probe given the low level of boss expression detected by Northern blot analysis (see Fig. 4). We have shown recently, however, that antibodies generated to two fusion proteins containing different regions of the proposed extracellular domain of the boss protein specifically stain the apical membranes of the R8 cell in wild type, but not in boss ${ }^{1}$ mutant eye discs (H. Krämer et al., in prep.).

\section{Structure of the boss gene}

The DNA sequence of boss was determined by dideoxy sequencing of genomic subclones and three overlapping cDNA clones (Fig. 5). Comparison between the genomic and the cDNA sequences defined four introns in the gene. Primer extension analysis indicates that the mRNA extends an additional 165 nucleotides upstream from the $5^{\prime}$ end of the longest cDNA (Fig. 6A). DNA sequence analysis revealed a consensus $3^{\prime}$ splice site (Shapiro and Senapathy 1987) at position 50 (Fig. 5). RNase protection analysis confirmed that position 51 is the first nucleotide of exon 2. Comparison of the primer extension and RNase protection results (Fig. 6) indicates that exon 2, containing the start of translation (see below), is preceded by an additional 50 nucleotides of exon sequence. We have not yet determined the size of the intron(s) separating the first two exons or the site of the initiation of transcription. The introns separating 


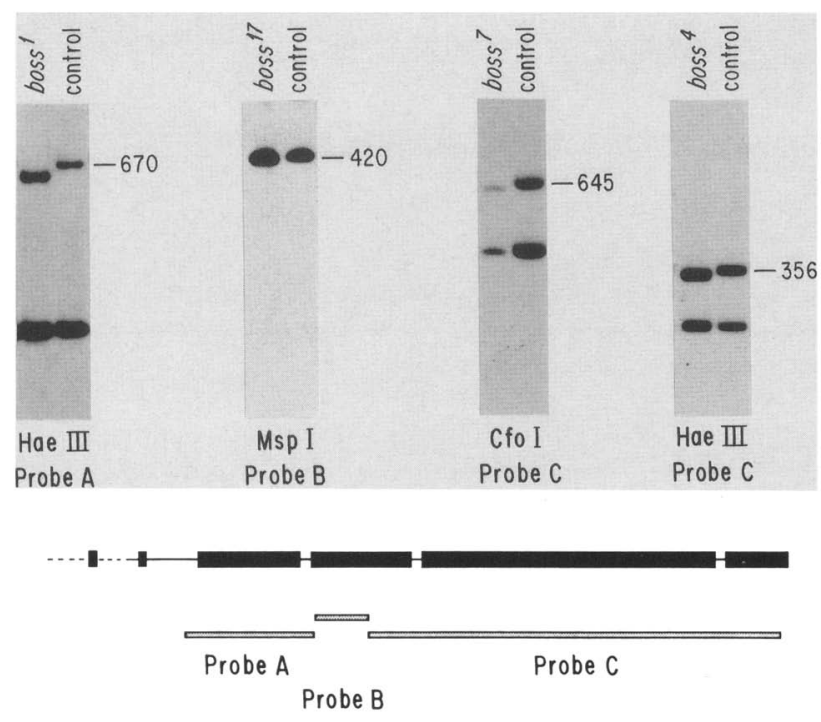

Figure 3. High-resolution Southern analysis of boss alleles. Mutant DNAs were cleaved with restriction endonuclease as indicated, followed by polyacrylamide gel electrophoresis and Southern blotting. The probes used on each blot correspond to genomic EcoRI restriction fragments located in the boss gene as illustrated. The boss gene structure is indicated above the probes, with solid bars representing exons, solid lines representing introns, and dashed lines indicating introns of unknown length (see text). Four alleles were shown to contain small deletions in the gene. The parental stocks were used as controls. The indicated sizes of the undeleted parental restriction fragments were determined by comparison with DNA marker fragments and subsequent sequence analysis of the boss genomic region. The precise size and position of each deletion is described in Fig. 5 and summarized in Fig. 8.

exons designated 2 and 3,3 and 4,4 and 5 , and 5 and 6 are $303,61,121$, and $61 \mathrm{bp}$, respectively. All splice sites fit the invertebrate consensus sequence (Shapiro and Senapathy 1987). Two canonical polyadenylation signals (Proudfoot and Brownlee 1976) are found 4 and 11 bp downstream from the most $3^{\prime}$ cDNA, designated F6. These are located 67 and $74 \mathrm{bp}$ after the stop codon, respectively. The length of the boss transcript from the start of transcription to the first polyadenylation site is $\sim 2990$ nucleotides, which is consistent with the size of the mRNA as determined from Northern blots.

DNA sequence analysis of mutant boss alleles: deletions leading to frameshifts in boss

Four boss alleles were shown to be small deletions, as determined by Southern blot analysis of small DNA fragments fractionated by polyacrylamide gel electrophoresis (see Fig. 3). The boss ${ }^{1}$, boss ${ }^{4}$, and boss ${ }^{7}$ alleles were generated by $\mathrm{X}$ rays. The boss ${ }^{17}$ allele was recovered in a P-element mutagenesis screen but does not carry P-element DNA within the boss gene. To determine the precise molecular defects in these mutants, the sequences of the altered regions of the mutant alleles were determined from cloned polymerase chain reaction (PCR) products. For each mutant and wild-type parental DNA, at least two clones from the initial amplification reactions were sequenced (for nucleotides deleted in each allele, see Fig. 5); all deletions were confirmed from analysis of independent amplification products. The amplified regions corresponded to the restriction fragments that showed alterations by Southern blot analysis. Each deletion results in a frameshift, causing premature translational termination (Figs. 5 and 8).

Our results concerning the nine boss alleles generated by $\mathrm{X}$ ray are similar to those reported previously for other loci. Five of nine X-ray-induced boss alleles are cytologically normal (see Table 1). Three of these mutations are due to deletions ranging in size from 2 to $23 \mathrm{bp}$, and one is due to an apparent small rearrangement not yet analyzed at the DNA sequence level. In previous studies of rosy and white alleles generated by $\mathrm{X}$ rays, $\sim 50$ to $70 \%$ were cytologically visible (Cote et al. 1986; Pastink et al. 1987). In the analysis of the white gene, Pastink et al. (1987) uncovered small deletions in four of five cytologically normal alleles, using $\mathrm{S} 1$ analysis, which were not detectable by conventional Southern blots. In contrast with the aforementioned study, deletions in the boss gene are not associated with small direct repeats.

\section{The boss protein sequence predicts a seven- transmembrane domain-containing protein}

Examination of the boss cDNA sequence revealed a single long open reading frame (ORF), which is predicted to encode a polypeptide of 896 amino acids. The four sequenced mutations are evenly distributed within this ORF (see Fig. 8, below). Four methionines are present in exon 2, the first two of which are followed by stop codons in the same reading frame. The third and fourth, which are 6 nucleotides apart, are in register with the long ORF. Translation is inferred to start at the first of these two methionines as they are preceded by an inframe stop codon. A hydrophobic stretch extending from amino acids 14 to 30 possesses features consistent with a cleavable signal sequence (von Heijne 1983). We pro-

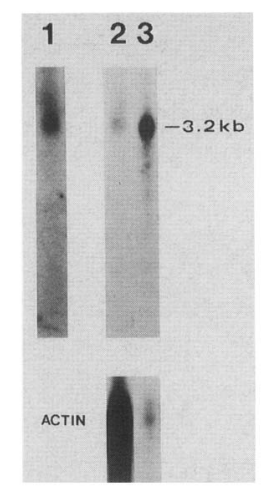

Figure 4. Northern blot analysis of the boss transcript. A Northern blot of poly $(\mathrm{A}))^{+}$RNA from a mixture of different imaginal discs (lane $1, \sim 25 \mu \mathrm{g}$ ) is shown probed with the boss F3 cDNA. For comparison, a fourfold lower exposure of this signal (lane 2) is shown next to that of the hybridization to poly(A) ${ }^{+}$RNA from adult head tissue (lane $\left.3,2 \mu \mathrm{g}\right)$. The same blot, reprobed with actin $5 \mathrm{C}$, is shown at bottom. 

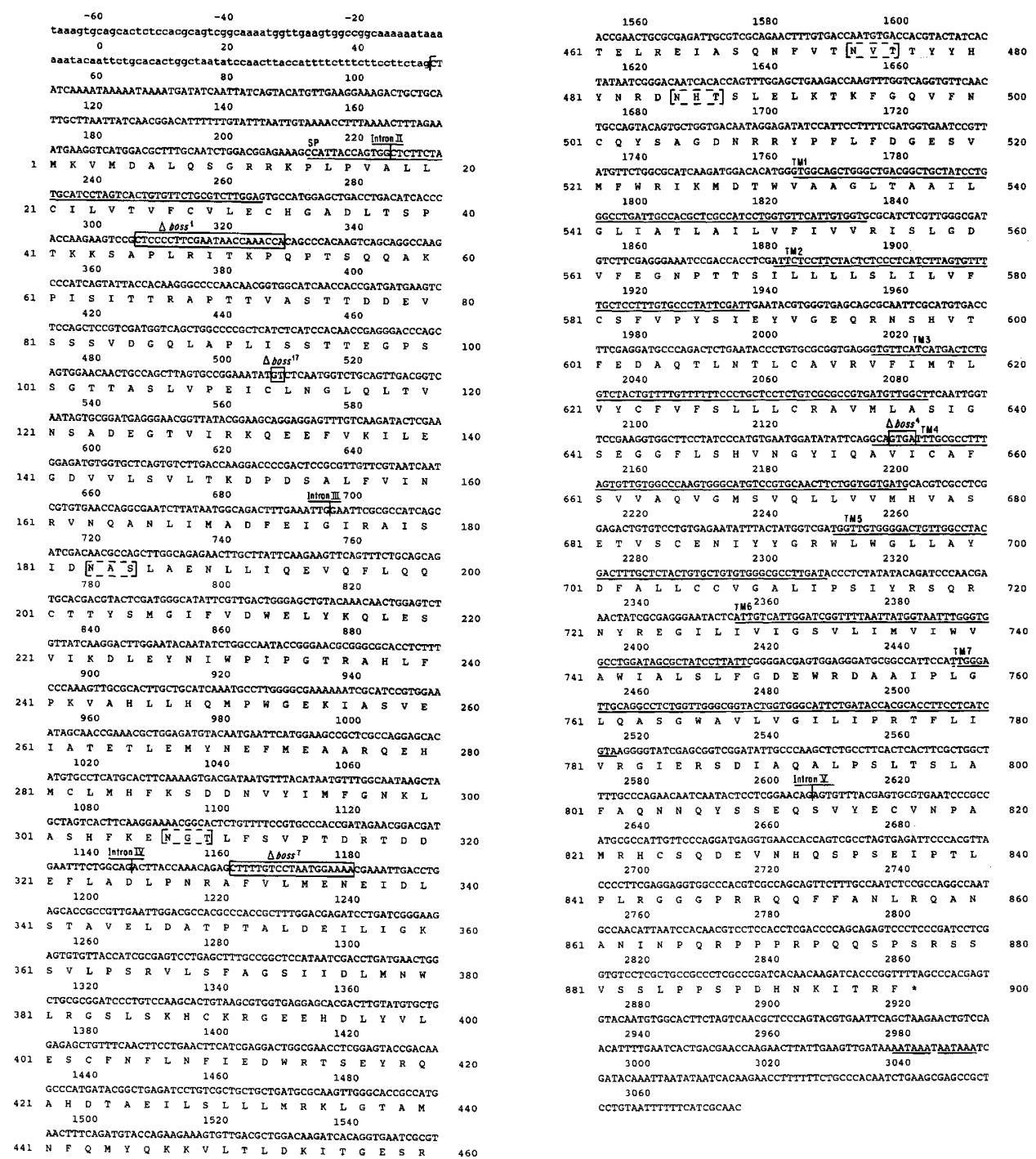

Figure 5. DNA sequence of the boss cDNA. The region from 164 to $2972 \mathrm{bp}$ was determined on both strands from genomic and cDNA clones. The remaining DNA sequence is derived from genomic clones only. The nucleotides in lowercase are part of intron 1 , based on the combined results of the primer extension and RNase protection experiments and the observed consensus splice acceptor site preceding position 51 (see Fig. 6). The putative signal peptide (SP) and the 7 TM domains (TM1-TM7) are indicated by a line above the amino acid sequence. The four potentional $\mathrm{N}$-glycosylation sites (NXT/S) are indicated by dashed boxes. The two putative polyadenylation signals (AATAAA) are underlined. The stop codon is indicated by an asterisk (*).

pose that the region following this signal sequence encodes an extracellular domain of 498 amino acids. Four putative sites for the addition of $\mathrm{N}$-linked sugars are found in this domain. The following 251 amino acids, encoded by a single exon, can be divided into seven regions of sufficient length and hydrophobicity to cross the plasma membrane (TM1-TM7) according to the algorithm of Kyte and Doolittle (1982; see Fig. 7). These regions are predicted to be between 19 and 24 amino acids in length. The TM1-TM6 domains have an average hydrophobicity $\geqslant 1.9$, whereas the TM7 domain is 1.8. According to Kyte and Doolittle (1982), a stretch of 19 amino acids in length, with an average hydrophobicity of 1.6 or greater, has a high probability of spanning the plasma membrane. The short amino acid sequences separating these hydrophobic regions are markedly hydrophilic. The carboxy-terminal 115 amino acids are proposed to be located cytoplasmically. The deduced sequence of the boss protein was found to have no statistically significant homology with proteins in the NBRF PROTEIN, NBRF NEW, and the EMBL-SWISS databases.

The hydropathy analysis reveals a surprising similarity in proposed membrane topology to the $G$ proteinlinked superfamily of receptors. A large number of these proteins, such as the rhodopsins and adrenergic and muscarinic acetylcholine receptors, form a family based on amino acid homology (e.g., Dohlman et al. 1987). In contrast, both the yeast a- and $\alpha$-factor receptors, which transduce signals in a $G$ protein-dependent fashion, do not have significant amino acid homology to this class or to one another but do contain a similar seven-transmembrane (7 TM) domain motif (Burkolder and Hartwell 1985; Hagen et al. 1986). Structural characteristics that are shared by most of the $\mathrm{G}$ protein-linked receptors 


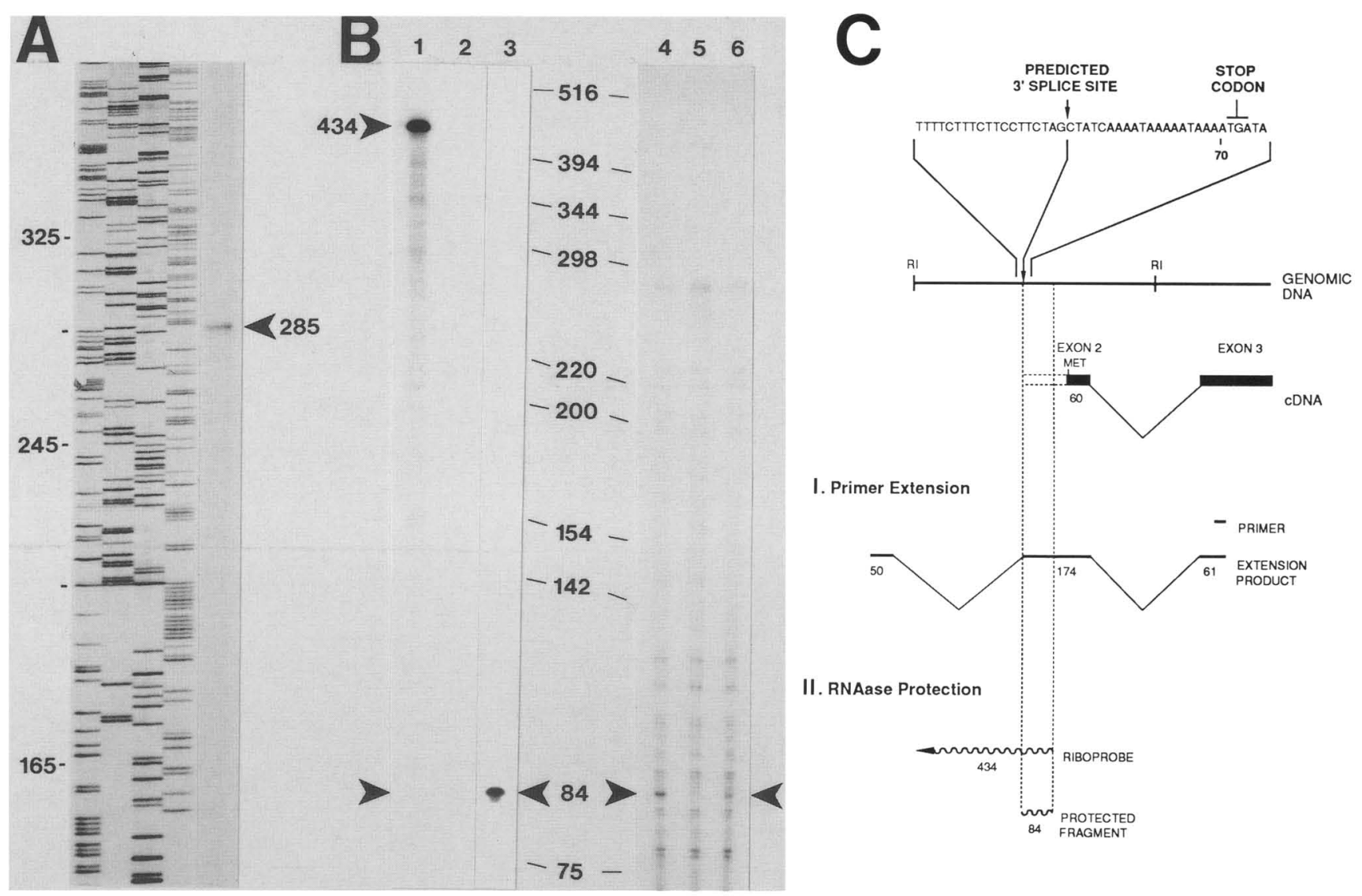

Figure 6. Structure of the $5^{\prime}$ end of the boss transcript. A summary of the strategies and results for both the primer extension $(A)$ and the RNase protection analysis $(B)$ is shown in $C$. $(A)$ Primer extension analysis: An oligonucleotide complementary to nucleotides 262-285 was used to prime synthesis of cDNA from wild-type head poly $(A)+$ RNA. A single 285-nucleotide extension product was observed (arrowhead), indicating a single major transcriptional initiation site mapping 185 bp upstream of the current 5 ' extent of the cDNA sequence. A sequencing ladder is shown at left as a molecular weight marker; hash marks indicate sizes at 40 -nucleotide intervals. $(B)$ Ribonuclease protection analysis: A 434-nucleotide riboprobe was generated from subclone p0.8 $\Delta 13$. This probe starts at nucleotide 135 (see Fig. 5). (Lanes 1 and 2) Probe hybridized with yeast tRNA (100 $\mu \mathrm{g}$ ) minus and plus RNase, respectively (see Materials and methods); (lane 3 ) a fragment protected by wild-type head poly $(\mathrm{A}))^{+} \mathrm{RNA}(\sim 2 \mu \mathrm{g})$ of $\sim 84$ nucleotides in length (arrowhead). In a separate experiment, the same riboprobe was hybridized to total RNA from head (100 $\mu g$; lane 4$)$ and imaginal disc (100 $\mu g$, lane 5), and to imaginal disc poly(A)+ RNA $(\sim 25 \mu \mathrm{g}$; lane 6$)$ and digested with RNases. A specific 84-nucleotide protected fragment is visible in lanes 4 and 6 (arrowheads) but is not detected in lane 5 . All nonspecific bands remain the same in lanes 4-6. The positions of molecular weight markers indicated in nucleotides are shown in the center. $(C)$ Schematic diagram of the experimental design: Schematic representations of the probes and products of the primer extension (I) and ribonuclease protection (II) analyses are shown. An excerpt of genomic sequence is shown to illustrate the location of the predicted 3 ' splice site for exon 2 at nucleotide 51 , upstream of the stop codon in the boss reading frame. Nucleotide numbers are indicated for comparison with the full-length sequence /see Fig. 5). The 5' extent of the boss cDNA clone F3 is indicated relative to the genomic EcoRI fragment containing exon 2 . The proposed initiator methionine (MET) is marked. Sizes in nucleotides are indicated below each product. It is not known whether the 50 nucleotides upstream of exon 2 in I are contained in a single exon. The position of this 50-nucleotide segment has not been determined. The 84-bp protected fragment in II corresponds to the distance between the $3^{\prime}$ splice site for exon 2 and the start of the probe at 135 bp.

and the predicted boss protein include the following: (1) The last extracellular loop is generally small. This is thought to facilitate the close apposition of the cytoplasmic loop between TM5 and TM6 and the cytoplasmic domain carboxy-terminal to TM7 /O'Dowd et al. 1989). Evidence suggests that these cytoplasmic regions are directly involved in $\mathrm{G}$ protein interactions (Strader et al. 1987; Dixon et al. 1988; O'Dowd et al. 1988). (2) The third cytoplasmic loop connecting TM5 and TM6 contains positively charged amino acids that can be arranged along one side of an amphipathic $\alpha$ - helix; this structure is thought to activate $G$ proteins (O'Dowd et al. 1989). (3) A cysteine is found in each of the first two short extracellular loops. In several cases, mutations have demonstrated that these two cysteines are required for receptor function (Dixon et al. 1988; Karnik et al. 1988; Nathans et al. 1989). These similarities between the predicted boss protein and this receptor superfamily suggest that boss encodes a distantly related member of this family and, accordingly, would be linked to a $G$ protein-mediated signal transduction pathway. 
A

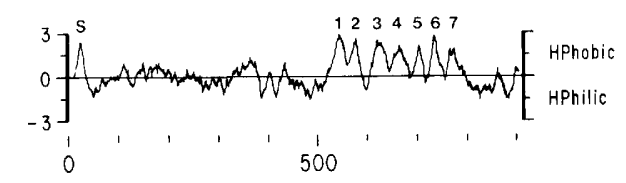

B

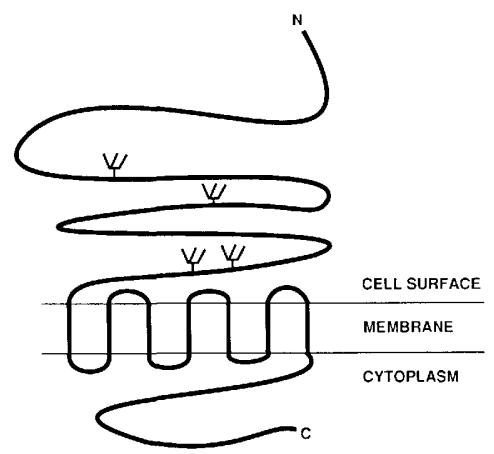

Figure 7. The boss protein has seven transmembrane segments. $(A)$ Hydropathy plot of the putative boss protein: The hydropathy of the predicted boss protein was determined according to the method of Kyte and Doolittle (1982), using a window of 19 amino acids. Peaks above 1.6 are likely to cross the membrane. The signal peptide (S) and the $7 \mathrm{TM}$ domains $(1-7)$ are indicated as predicted (see text). Amino acid position is indicated along the $\mathrm{x}$-axis; hydrophathy is along the $\mathrm{y}$-axis. $(B)$ Predicted structure of the boss protein: The proposed membrane topology is based on a hydropathy analysis $(A)$. The boss protein is predicted to have a cleaved amino-terminal signal sequence (not shown). Consequently, the amino terminus is depicted as extracellular (498 amino acids). The potential N-glycosylation sites are indicated. The carboxy-terminal 115 amino acids are predicted to lie cytoplasmically.

\section{Discussion}

Inductive interactions between specific cells have been proposed to regulate cell fate in the Drosophila compound eye (Tomlinson and Ready 1987a). The demonstrated requirement of boss expression in $\mathrm{R} 8$ for the development of only one of its neighbors, the $\mathrm{R} 7$ photoreceptor neuron, provided the first genetic support for this model (Reinke and Zipursky 1988). The proposed membrane topology of the boss protein with its large extracellular domain reported in this paper, as well as our recent findings that the boss protein is specifically expressed on the apical membranes of the R8 cell $(\mathrm{H}$. Krämer et al., in prep. I, argue for a direct role for the boss protein in mediating cell-cell interactions in the developing eye disc.

We consider two classes of potential mechanisms for the boss protein: (1) a ligand that directly interacts with the sev receptor, and (2) a receptor in R8 for an extracellular cue that regulates $\mathrm{R} 8$ induction of the $\mathrm{R} 7$ cell. As a ligand, the boss protein could function either tethered to the surface of R8 by the 7 TM domains or as locally diffusible peptide proteolytically released from the cell sur- face. If the boss protein does function as a tethered ligand, it is conceivable that the 7 TM domain may allosterically regulate its activity. In the case of HMG-CoA reductase, the stability of the catalytic domain is regulated by a 7 TM domain (Gil et al. 1985). Moreover, the ligand affinity of the $\beta$-adrenergic receptor is modulated by $G$ protein interactions (Strader et al. 1987). Hence, the affinity of the boss protein for the sev receptor could be controlled by signaling events in R8.

Although a model in which the boss protein functions as a ligand is consistent with the available data, its $7 \mathrm{TM}$ carboxy-terminal domain raises the intriguing possibility that boss encodes a receptor. This unexpected receptor-like structure raises the important issue of whether boss is critical for R8 development per se and only secondarily influences R7 development or whether its only role in R8 is to induce R7 development. Recent studies using ectopic expression of the homeo-box-containing rough gene (Basler et al. 1990; Kimmel et al. 1990) argue for its role in establishing R2/R5 cell identity rather than directly controlling the expression of inductive cues in cells required for R3/R4 development, as

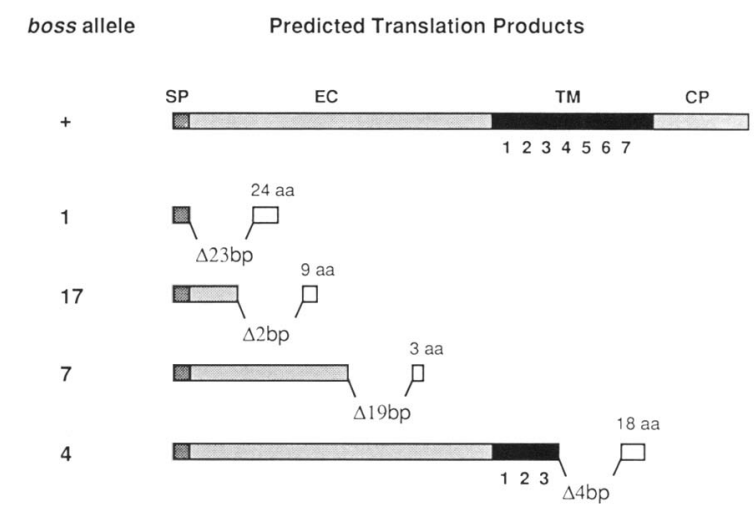

Figure 8. The predicted structure boss proteins encoded by mutant alleles. The predicted signal sequence (SP), the large extracellular domain (EC), the 7 TM domain (TM1-TM7), and the intracellular domain (CP) of the wild-type boss proteins $(+)$ are shown schematically. The predicted translation products of the sequenced mutant alleles are shown below (for sequence, see Fig. 5). For each allele, the size of the deletion leading to a frameshift and the number of amino acids encountered before the termination codon are indicated. The boss ${ }^{1}$ allele is the largest deletion, removing the 23 nucleotides between nucleotide 306 and nucleotide 328 . This deletion results in a frameshift in which the codon for amino acid 45 is changed but still encodes an alanine, and an additional 24 amino acids are added. The boss ${ }^{17}$ allele carries a 2 -nucleotide deletion removing nucleotides 507 and 508. As a result, it converts codon 112 into a serine, which is then followed by an additional 8 amino acids. The $b^{\circ} s^{7}$ allele is a 19-bp deletion, removing nucleotides 1161-1179. The resultant frameshift leads to change in codon 330 in which the encoded amino acid remains alanine and the addition of three amino acids. Finally, the boss ${ }^{4}$ allele is the result of a 4-bp deletion within the region proposed to encode the fourth of the 7 TM domains. This deletion of nucleotides 2138-214l causes a frameshift resulting in amino acid 656 becoming phenylalanine, followed by an additional 17 amino acids (for sequence, see Fig. 5). 
proposed previously (Tomlinson et al. 1988). Several lines of evidence including morphological and molecular criteria argue against a similar role for boss in regulating R8 development (see Results).

If the boss protein is a receptor, how could it function in $\mathrm{R} 8$ to control R7 development? In principle, the boss protein could regulate the release or biosynthesis of an inductive signal. In this regard it is important to note that the activation of $\mathrm{G}$ proteins by ligand binding to the 7 TM domain class of receptors can result directly in secretion (e.g., Gomperts and Tatham 1988; Penner and Neher 1988; Knight et al. 1989) or changes in gene expression (e.g., Kesbeke et al. 1988; Arenander et al. 1989). Thus, in the case of boss, ligand binding would result in the activation of a $G$ protein-mediated signal transduction cascade in R8, leading directly to the presentation of the cue inducing R7. In this capacity, boss would regulate the release of a specific ligand much the way that receptors for gonadatropin-releasing hormones, secreted by the hypothalamus, are thought to regulate the release of luteinizing hormone and follicle-stimulating hormone from the anterior pituitary gland (Conn et al. 1987).

The regulated release of developmental cues by cellcell interaction would provide a mechanism for precise spatial and temporal control of inductive events. Indeed, it has been speculated that the ligand recognized by the sev protein will be highly restricted. This view is based on the observation that $\mathrm{sev}$ is expressed in more cells than R7 (Banerjee et al. 1987; Tomlinson et al. 1987). Furthermore, misexpression of sev protein at high levels in all cells within the developing ommatidium does not lead to the development of additional R7 cells (Basler and Hafen 1989; Bowtell et al. 1989|. The recent analysis of the seven up mutation, where certain $\mathrm{R}$ cells fail to assume their normal fates and are capable of responding to the R7 inductive cue, supports the notion that the presentation of this signal follows the determination of these other R cells (Mlodzik et al. 1990). If the boss protein is a ligand for the sev protein, its effect could be restricted by strict spatiotemporal regulation of its expression, via transcriptional, translational, or post-translational mechanisms. Alternatively, if the boss protein is a receptor, it could, in principle, provide a mechanism for timing the presentation of an inductive cue to a period in which the $\mathrm{R} 7$ precursor is the only uncommitted cell contacting R8. One possible mechanism for accomplishing this temporal coordination would involve signals from differentiating $R$ cells, which would signal $\mathrm{R} 8$ via boss protein to induce $\mathrm{R} 7$ development.

Regulated expression or secretion of inductive cues has recently been implicated in the developmental logic of several other systems. Recent studies reported by Lillien et al. (1988) suggest that the bipotential fate of the O-2A precursor in the rat optic nerve is not controlled by the responsivity of the $\mathrm{O}-2 \mathrm{~A}$ precursor cell but, rather, by the temporally regulated release or synthesis of ciliary neurotrophic factor (CNTF). As in the case of the sev receptor, other tyrosine kinase receptors with widespread distributions are only locally activated during development. For instance, the Drosophila gene product torso, predicted to encode a membrane-bound tyrosine kinase (Sprenger et al. 1989), is uniformly distributed along the surface of the early embryo but is active only at the termini (Casanova and Struhl 1989). It has been speculated that this activation is the result of selective localization of the ligand to the anterior and posterior poles of the embryo. Similarly, Gillespie et al. (1989) have shown that the bFGF receptor is distributed at comparable levels throughout the Xenopus embryo. Thus, the localized effects of bFGF in mesodermal induction may also reflect the regulated release or biosynthesis of this growth factor.

Little is known about the role of 7 TM class of receptors in regulating extracellular cues during development. In this context, it is interesting to note that two 7 TM domain-containing proteins, the Dictyostelium cAMP receptor (Klein et al. 1988) and the Drosophila frizzled protein (Vinson et al. 1989), appear to be involved in interpreting and transmitting developmental cues. During Dictyostelium aggregation, the cAMP receptor not only responds to CAMP, it also stimulates further synthesis and release of cAMP. In genetic mosaic analyses, some alleles of the Drosophila frizzled gene have been shown to be cell autonomous, whereas others are cell nonautonomous (Vinson and Adler 1987). These data led Vinson and Adler (1987) to suggest that the frizzled gene function is required for both response to, and subsequent transmission of, polarity information within the wing.

In summary, the structure of the boss protein proposed in this paper raises the question of whether it functions as a conventional receptor controlling R7 induction or as an unconventional ligand for the sev receptor. Future experiments using genetic and biochemical approaches will be used to distinguish between these models.

\section{Materials and methods}

\section{Genetics}

A description of strains and genetic markers used can be found in Lindsley and Grell (1968). The isolation and recombination mapping of boss ${ }^{1}$ and the phototactic choice tests used to identify all of the boss alleles were described previously (Reinke and Zipursky 1988). The $E(s p 1)^{B X 21}$ mutant was obtained from A. Preiss and S. Artavanis-Tsakonas (Preiss et al. 1988). The strain used in recombination analysis, carrying a transposon marked with neomycin and the Rhl promoter fused to Escherichia coli $\beta$-galactosidase, was obtained from Mismer and Rubin (1987). Additional X-ray and chemically induced alleles of boss were isolated in an $F_{1}$ screen of progeny from mutagenized males crossed to boss ${ }^{1}$ virgins, using the phototactic choice test (see Reinke and Zipursky 1988). A strain marked with hairy ${ }^{2}$ was mutagenized with $\mathrm{X}$ rays and EMS, as described by Grigliatti (1986). Seven alleles from $\sim 35,000$ males screened were generated by using X-ray irradiation, whereas 4 EMS mutants were isolated from $\sim 32,000$ males screened. A radius incompletus, ebony strain was mutagenized with diepoxybutane as described by Kaufmann and co-workers (Bender et al. 1987). Two boss mutants were generated for $\sim 10,000$ males screened. In a screen of $\sim 300,000$ chromosomes mutagenized by hybrid dysgenesis, we obtained four alleles, none of which contained $\mathrm{P}$ insertions into the boss gene. (For a summary of the boss al- 
leles, see Table 1.) Cytological examination of polytene chromosomes was done using protocol II in Pardue (1986), but without the $\mathrm{HCl}$ treatment.

\section{Isolation and analysis of RNA and DNA}

Genomic DNA was prepared as described by Meyerowitz et al. (1980). Total RNA was prepared from Drosophila heads, as described by Chirgwin et al. (1979). Imaginal discs were prepared according to Eugene et al. (1979), and RNA was isolated by using the method of Cathala et al. (1983). Poly(A)+ selection was performed according to standard procedures (Maniatis et al. 1982), by using oligo(dT)-cellulose. Northern blotting from formaldehyde-agarose gels to Zeta-Probe nylon membrane was done as recommended by the manufacturer (Bio-Rad). Drosophila genomic clones were isolated by standard methods (Perbal 1984) from an amplified Oregon-R (Ore-R) wild-type library in EMBL3 (generous gift of $M$. Tanouye), using terminal $E c o R I$ restriction fragments from clones $\lambda \mathrm{E} 12$ and $\lambda \mathrm{E} 9$ (generously provided by E. Knust and J. Campos-Ortega) as probes. All probes were radiolabeled by random priming, as described by Feinberg and Vogelstein (1983). cDNA clones were isolated from a head cDNA library constructed in $\lambda$ gt 10 from a wildtype Ore- $R$ strain (generous gift of $C$. Zuker).

\section{High-resolution Southern blot analysis}

Genomic DNAs were cut with restriction enzymes and separated on $6 \%$ polyacrylamide gels ( $1.5 \mathrm{~mm}$ thick) for $6 \mathrm{hr}$ at 320 $\mathrm{V}(8 \mathrm{~V} / \mathrm{cm})$ in TBE buffer (Maniatis et al. 1982). Gels were stained with ethidium bromide, photographed, denatured for 20 min, neutralized, and equilibrated before transfer on ZetaProbe. DNA was electrophoretically transferred for $18 \mathrm{hr}$ at 200 $\mathrm{mA}, 6 \mathrm{~V}$, in $0.5 \times \mathrm{TBE}$ buffer. The blots were processed as suggested by the manufacturer (Bio-Rad).

\section{DNA sequencing and computer analysis}

A set of nested deletions of genomic and cDNA subclones were obtained by using exonuclease III and mung bean nuclease (Stratagene). Double-stranded plasmid DNA was sequenced by using the T3 and T7 primers (Stratagene) or specifically synthesized primers (Operon Technologies, Inc.) by the chain-termination sequencing method (Sanger et al. 1977) modified for Sequenase (U.S. Biochemicals). Both strands of the genomic DNA and cDNA were sequenced. Regions prone to compressions were resequenced by using 7-deaza-dGTP (U.S. Biochemicals). The sequences surrounding the EcoRI restriction sites used for subcloning the genomic DNA fragments were obtained from at least two independently amplified and cloned PCR products spanning the sites. This enabled us to identity one 9-bp EcoRI fragment that was lost during subcloning of the genomic restriction fragments. The cDNA sequence is a composite of the sequences of the clones F3 (2752 nucleotides from position 164 to 2916); F10, which is totally contained within F3 (1927 nucleotides from position 982 to 2916); and F6, which was partially sequenced because it contains a $3^{\prime}$ extension of $57 \mathrm{bp}$. Compilation of DNA sequences and their analysis was done with the University of Wisconsin GCG (UWGCG) software package (Devereux et al. 1984). The hydrophobicity profile of the boss protein was determined by using PEPPLOT (UWGCG), based on the algorithm of Kyte and Doolittle (1982). Searches for amino acid homologies with other proteins in the NBRF PROTEIN, NBRF NEW, and EMBL-SWISS data bases were done with the program FAST-P (Lipman and Pearson 1985).

$P C R$, RNase protection, and primer extension

Amplification of genomic DNA fragments using PCR was optimized from protocols described by Erlich (1989). Mutant and parental control fragments were amplified for four different boss alleles. The sequence was determined from at least two subclones. Each identified deletion was verified from two independent PCR samples. None of the reaction products from a wild-type DNA showed a deletion. RNase protection was carried out essentially as described by Ausubel et al. (1989), using uniformly ${ }^{32} \mathrm{P}$-labeled riboprobes. Riboprobes were generated from $\mathrm{pBSKS}^{+}$subclone $\mathrm{p} 8 \Delta 13$ by using either T3 or T7 RNA polymerase (Promega). For primer extensions, ${ }^{32} \mathrm{P}$-labeled oligonucleotide primers were annealed to head poly $(\mathrm{A}))^{+} \mathrm{RNA} / 2$ $\mu \mathrm{g})$ and were extended with 10 units of AMV reverse transcriptase (Boehringer Mannheim) in buffer containing $40 \mathrm{~mm}$ Tris$\mathrm{HCl}$ (pH 8.0), $10 \mathrm{mM} \mathrm{MgCl}, 2.5 \mathrm{~mm} \mathrm{DTT}, 75 \mathrm{~mm} \mathrm{NaCl}$, and 0.3 mM dNTPs.

Immunohistology

Eye-antennal imaginal discs were dissected in PBS from wandering third-instar larvae and stained essentially as described by Stellar et al. (1987). Purified rat anti-elav antibody was obtained from K. White (Robinow et al. 1988), and anti- $\beta$-galactosidase antibodies were obtained from Promega. In all cases, HRP-conjugated second antibody (Organon Teknika Corp., Cappell Laboratories) was used. For anti-elav staining, the HRP substrate 3 -amino-9-ethyl carbazole was used, whereas with anti- $\beta$-galactosidase antibody the HRP substrate was $3,3^{\prime}$-diaminobenzidine.

\section{Acknowledgments}

We are particularly indebted to Barbara Thomas, Ross Cagan, and William Biggs for reagents and help with histology, Aviv Siegal for excellent technical assistance, and Rebecca Hess for the isolation of several of the boss $\mathrm{P}$ alleles. We gratefully acknowledge the help of Annette Preiss, Elizabeth Knust, Jose Campos-Ortega, and Spiros Artavanis-Tsakonas for providing $E$ (spl) stocks and genomic clones. We thank David Eisenberg and Roland Luethy for help with the computer analysis. The anti-elav antibody and the head cDNA library were the generous gifts of Kalpana White and Charles Zuker, respectively. We are grateful to Eddy DeRobertis, Utpal Banerjee, and Steve Crews, as well as the members of the Zipursky lab, for careful reading of the manuscript and helpful comments. This work was supported by a U.S. Public Health Service National Research Service Award (GM-07104; A.C.H.), and an EMBO postdoctoral fellowship (H.K.), predoctoral fellowships from the National Institutes of Health (NIH) (D.V.V.) and National Institute of Mental Health (D.V.V.), research grants from the National Science Foundation (BNS 8608085) and the NIH (1R01 EY08772-01), and awards from the McKnight and Sloan Foundations.

The publication costs of this article were defrayed in part by payment of page charges. This article must therefore be hereby marked "advertisement" in accordance with 18 USC section 1734 solely to indicate this fact.

\section{Note added in proof}

Using P-element-mediated DNA transformation we have rescued the boss ${ }^{1}$ mutant allele with an $8.5-\mathrm{kb}$ genomic fragment, which includes the boss transcript. The nucleotide sequence data will appear in the EMBL, GenBank, and DDBJ Nucleotide Sequence databases under accession number X55887.

\section{References}

Anderson, D.J. and R. Axel. 1985. Molecular probes for the development and plasticity of neural crest derivatives. Cell 42: 649-662. 
Arenander, A.T., J. De Vellis, and H.R. Herschman. 1989. Induction of c-fos and TIS genes in cultured rat astrocytes by neurotransmitters. J. Neurosci. Res. 24: 107-114.

Artavanis-Tsakonas, S. 1988. The molecular biology of the Notch locus and the fine tuning of differentiation of in Drosophila. Trends Neurosci. 4: 95-100.

Ausubel, F., R. Brent, R.E. Kingston, D.D. Moore, J.G. Seidman, J.A. Smith, and K. Struhl. eds. 1989. Current protocols in molecular biology. Greene Publishing Associates/Wiley Interscience, New York.

Banerjee, U. and S.L. Zipursky. 1990. The role of cell-cell interaction in the development of the Drosophila visual system. Neuron 4: 177-187.

Baneriee, U., P.J. Renfranz, J.A. Pollock, and S. Benzer. 1987a. Molecular characterization and expression of sevenless, a gene involved in neuronal pattern formation in the Drosophila eye. Cell 49: 281-291.

Banerjee, U., P.J. Renfranz, D.R. Hiniton, B.A. Rabin, and S. Benzer. $1987 \mathrm{~b}$. The sevenless ${ }^{+}$protein is expressed apically in cell membranes of developing Drosophila retina; it is not restricted to cell R7. Cell 51: 151-158.

Basler, K. and E. Hafen. 1988. Control of photoreceptor cell fate by the seveneless protein requires a functional tyrosine kinase domain. Cell 54: 299-311.

- 1989. Ubiquitous expression of sevenless: Position-dependent specification of cell fate. Science 243: 931-934.

Basler, K., D. Yen, A. Tomlinson, and E. Hafen. 1990. Reprogramming cell fate in the developing Drosophila retina; transformation of R7 cells by ectopic expression of rough. Genes Dev. 4: 728-739.

Bender, M., F.R. Turner, and T.C. Kaufman. 1987. A developmental genetic analysis of the gene regulator or postbithorax in Drosophila melanogaster. Dev. Biol. 119: 418432.

Bowtell, D.D.L., M.A. Simon, and G.M. Rubin. 1988. Nucleotide sequence and structure of the sevenless gene of Drosophila melanogaster. Genes Dev. 2: 620-634.

1989. Ommatidia in the developing Drosophila eye require and can respond to sevenless for only a restricted period. Cell 56: 931-936.

Burkholder, A.C. and L.H. Hartwell. 1985. The yeast $\alpha$-factor receptor: Structural properties deduced from the sequence of the STE2 gene. Nucleic Acids Res. 13: 8463-8475.

Campos-Ortega, J.A., G. Jurgens, and A. Hofbauer. 1979. Cell clones and pattern formation: Studies on sevenless, a mutant of Drosophila melanogaster. Roux's Arch. Ent. Org. 186: $27-50$.

Casanova, J. and G. Struhl. 1989. Localized surface activity of torso, a receptor tyrosine kinase, specifies terminal body pattern in Drosophila. Genes Dev. 3: 2025-2038.

Cathala, G., J.-F. Savouret, B. Mendez, B.L. West, M. Karin, J.A. Martial, and J.D. Baxter. 1983. A method for isolation of intact, translationally active ribonucleic acid. DNA 2: 329335.

Chirgwin, J., A. Pryzbyla, R. McDonald, and W. Rutter. 1979. Isolation of biologically active ribonucleic acid from sources enriched in ribonucleases. Biochemistry 18: 5294-5299.

Conn, P.M., W.R. Huckle, W.V. Andrews, and C.A. McArdle. 1987. The molecular mechanism of action of gonadatropin releasing hormone (GnRH) in the pituitary. Recent Prog. Horm. Res. 43: 29-68.

Cote, B., W. Bender, D. Curtis, and A. Chovnick. 1986. Molecular mapping of the rosy locus in Drosophila melanogaster. Genetics 112: 769-783.

Devereux, J., P. Haekerli, and O. Smithies. 1984. A comprehensive set of sequence programs for the VAX. Nucleic Acids Res. 11: 1645-1655.
Dixon, R.A.F., I.S. Sigal, and C.D. Strader. 1988. Structurefunction analysis of the $\beta$-adrenergic receptor. Cold Spring Harbor Symp. Quant. Biol. 63: 487-497.

Dohlman, H.G., M.G. Caron, and R.J. Lefkowitz. 1987. A family of receptors coupled to guanine nucleotide regulatory proteins. Biochemistry 26: 2657-2664.

Erlich, H.A., ed. 1989. PCR technology: Principles and applications for DNA amplification. Stockton Press, New York.

Eugene, O., M.A. Yund, and J.W. Fristrom. 1979. Preparative isolation and short-term organ culture of imaginal discs of Drosophila melanogaster. Tissue Culture Assoc. Manual 5: 1055-1062.

Feinberg, A.P. and B. Vogelstein. 1983. A technique for radiolabelling DNA restriction endonuclease fragments to high specific activity. Anal. Biochem. 132: 6-13.

Franceschini, N. and K. Kirschfeld. 1971a. In vivo optical study of photoreceptor cell elements in the compound eye of Drosophila. Kybernetik 8: 1-13.

- 1971b. Pseudopupil phenomena in the compound eye of Drosophila. Kybernetik 9: 159-182.

Fujita, S.C., S.L. Zipursky, S. Benzer, A. Ferrus, and S.L. Shotwell. 1982. Monoclonal antibodies against the Drosophila nervous system. Proc. Natl. Acad. Sci. 79: 7929-7933.

Garcia-Bellido, A. and J.R. Merriam. 1969. Cell lineage of the imaginal discs in Drosophila gynandromorphs. J. Exp. Zool. 170: $61-76$.

Gil, G., J.R. Faust, D.J. Chin, J.L. Goldstein, and M.S. Brown. 1985. Membrane-bound domain of HMGCo-A reductase is required for sterol-enhanced degradation of the enzyme. Cell 41: $249-258$.

Gillespie, L.L. G.D. Paterno, and J.M.W. Slack. 1989. Analysis of competence: Receptors for fibroblast growth factor in early embryos. Development 106: 203-208.

Gomperts, B.D. and P.E.R. Tatham. 1988. GTP-binding proteins in the control of exocytosis. Cold Spring Harbor Symp. Quant. Biol. 63: 983-992.

Greenwald, I. 1989. Cell-cell interactions that specify certain cell fates in $C$. elegans development. Trends Genet. 56: $237-241$.

Grigliatti, T. 1986. Mutagenesis. In Drosophila: A practical approach (ed. D.B. Roberts), pp. 39-58. IRL Press Ltd., Oxford.

Hafen, E., K. Basler, J.E. Edstroem, and G.M. Rubin. 1987. sevenless, a cell-specific homeotic gene of Drosophila, encodes a putative transmembrane receptor. Science 236: 5563.

Hagen, D.C., G. McCaffrey, and G.F. Sprague, Jr. 1986. Evidence the yeast STE3 gene encodes a receptor for the peptide pheromone a factor: Gene sequence and implications for the structure of the presumed receptor. Proc. Natl. Acad. Sci. 83: $1418-1422$.

Harris, W.A., W.S. Stark, and J.A. Walker. 1976. Genetic dissection of the photoreceptor system in the compound eye of Drosophila melanogaster. I. Physiol. 256: 415-439.

Karnik, S.S., T.P. Sakmar, H.-B. Chen, and H.G. Khorana. 1988. Cysteine residues 110 and 187 are essential for the formation of correct structure in bovine rhopdopsin. Proc. Natl. Acad. Sci. 85: 8459-8463.

Kesbeke, F., B.E. Snaar-Jagalska, and P.J.M. Van Haastert. 1988. Signal transduction in Dictyolstelium FGD A mutants with a defective interaction between surface cAMP receptor and a GTP-binding regulatory protein. I. Cell. Biol. 107: 521-528.

Kimmel, B.E., U. Heberlein, and G.M. Rubin. 1990. The homeo domain protein rough is expressed in a subset of cells in the developing Drosophila eye where it can specify photoreceptor cell subtype. Genes Dev. 4: 712-727.

Klein, P.S., J.S. Tzeli, C.L. Saxe, III, A.R. Kimmel, R.L. Johnson, and P.N. Devreotes. 1988. A chemoattractant receptor con- 
trols development in Dictyostelium discoideum. Science 241: 1467-1472.

Knight, D.E., H. von Grafenstein, and C.M. Athayde. 1989. Calcium-dependent and calcium-independent exocytosis. Trends Neurosci. 11: 451-458.

Knust, E., K. Tietze, and J.A. Campos-Ortega. 1987. Molecular analysis of the neurogenic locus Enhancer of split of Drosophila melanogaster. EMBO 1. 6: 4113-4123.

Kyte, J. and R. Doolittle. 1982. A simple method for displaying the hydropathic character of a protein. J. Mol. Biol. 157: $105-132$.

Lawrence, P.A. and S.M. Green. 1979. Cell lineage in the developing retina of Drosophila Dev. Biol. 71: 142-152.

Lebovitz, R. and D.F. Ready. 1986. Ommatidial development in eye disc fragments. Dev. Biol. 117: 663-671.

Lillien, L.E., M. Sendter, H. Rohrer, S.M. Hughes, and M.C. Raff. 1988. Type-2 astrocyte development in rat brain cultures in initiated by a CNTF-link protein produced by type-1 astrocytes. Neuron 1: 485-494.

Lindsley, D.L. and E.H. Grell. 1968. Genetic variations of Drosophila melanogaster. Carnegie Inst. Wash. Publ. 627.

Lipman, D. and W. Pearsosn. 1985. Rapid and sensitive protein similarity searches. Science 227: 1435-1441.

Maniatis, T., E.F. Fritsch, and J. Sambrook. 1982. Molecular cloning: A laboratory manual. Cold Spring Harbor Laboratory, Cold Spring Harbor, New York.

Meyerowitz, E.M., G.M. Guild, L.S. Prestidge, and D.S. Hogness. 1980. A new high capacity cosmid vector and its use. Gene 11: 271-282.

Mismer, D. and G.M. Rubin. 1987. Analysis of the nina E opsin gene in Drosophila melanogaster. Genetics 116: 565-578.

Mlodzik, M., Y. Hiromi, U. Weber, C.S. Goodman, and G.M. Rubin. 1990. The Drosophila seven up gene, a member of the steriod receptor gene superfamily, controls photoreceptor cell fates. Cell 60: 211-224.

Nathans, J., C.M. Davenport, I.H. Maumenee, R.A. Lewis, J.F. Hejtmancik, M. Litt, E. Lovrien, R. Weleber, B. Bachynski, F. Zwas, R. Klingaman, and G. Fishman. 1989. Molecular genetics of human blue cone monochromacy. Science 245:831-838.

O'Dowd, B.F., R.J. Lefkowitz, and M.G. Caron. 1989. Structure of the adrenergic and related receptors. Annu. Rev. Neurosci. 12: $67-83$.

O'Kane, C. and W.J. Gehring. 1987. Detection in situ of genomic regulatory elements in Drosophila. Proc. Natl. Acad. Sci. 84: 9123-9127.

Pardue, M.L. 1986. In situ hybridization of DNA to chromosomes and nuclei. In Drosophila: A practical approach led. D.B. Roberts), pp. 111-138. IRL Press, Oxford.

Pastink, A., A.P. Schalet, C. Vreeken, E. Pardi, and J.C.J. Eeken. 1987. The nature of radiation-induced mutations at the white locus of Drosophila melanogaster. Mutat. Res. 177: $101-115$.

Penner, R. and E. Neher. 1988. The role of calcium in stimulussecretion coupling in excitable and non-excitable cells. $J$. Exp. Biol. 139: 329-345.

Perbal, B. 1984. A practical guide to molecular cloning. John Wiley, New York.

Preiss, A., D.A. Hartley, and S. Artavanis-Tsakonas. 1988. The molecular genetics of Enhancer of split, a gene required for embryonic neural development in Drosophila. EMBO $J$. 7: 3917-3927.

Proudfoot, N. and G. Brownlee. 1976. 3' Non-coding region sequences in eukaryotic mRNA. Nature 263: 211-214.

Raff, M.C., L.E. Lillien, W.D. Richardson, J.F. Burne, and M.D. Noble. 1988. Platelet-derived growth factor from astrocytes drives the clock that times oligodendrocyte development in culture. Nature 333: 562-565.

Ready, D.F. 1989. A multifaceted approach to neural development. Trends Neurosci. 12: 102-109.

Ready, D.F., T.E. Hanson, and S. Benzer. 1976. Development of the Drosophila retina, a neurocrystalline lattice. Dev. Biol. 53: $217-240$.

Reinke, R. and S.L. Zipursky. 1988. Cell-cell interaction in the Drosophila retina: The bride of seveneless gene is required in cell R8 for R7 cell development. Cell 55: 321-330.

Robinow, S., A.R. Campos, K.-M. Yao, and K. White. 1988. The elav gene product of Drosophila, required in neurons, has three RNP consensus motifs. Science 242: 1570-1572.

Rubin, G.M. 1989. Development of the Drosophila retina: Inductive events studied at single cell resolution. Cell 57: 519-520.

Sanger, F., S. Nicklen, and A. Coulson. 1977. DNA sequencing with chain-terminating inhibitors. Proc. Natl. Acad. Sci. 74: $5463-5467$

Shapiro, M.B. and P. Senapathy. 1987. RNA splice junctions of different classes of eukaryoties: Sequence statistics and functional implications in gene expression. Nucleic Acids Res. 15: 7155-7174.

Sprenger, F., L.M. Stevens, and C. Nüsslein-Volhard. 1989. The Drosophila gene torso encodes a putative receptor tyrosine kinase. Nature 338: 478-483.

Steiler, H., K.-F. Fischbach, G.M. Rubin. 1987. disconnected: A locus required for neuronal pathway, formation in the visual system of Drosophila Cell 5: 1139-1153.

Strader, C.D., R.A.F. Dixon, A.H. Cheung, M.R. Candelore, A.D. Blake, and L.S. Sigal. 1987. Mutations that uncouple the $\beta$-adrenergic receptor from $G_{s}$ and increase agonist affinity. J. Biol. Chem. 262: 16439-16443.

Tomlinson, A. 1985. The cellular dynamics of pattern formation in the eye of Drosophila. J. Embryol. Exp. Morphol. 89: 313-331.

-1988. Cellular interactions in the developing Drosophila eye. Development 104: 183-189.

Tomlinson, A. and D.F. Ready. 1986. sevenless, a cell specific homeotic mutation of the Drosophila eye. Science 231: $400-402$.

-1987a. Neuronal differentiation in the Drosophila ommatidium. Dev. Biol. 120: 366-376.

1987b. Cell fate in Drosophila ommatidium. Dev. Biol. 123: $264-275$.

Tomlinson, A., D.D.L. Bowtell, E. Hafen, and G.M. Rubin. 1987. Localization of the sevenelss protein, a putative receptor for positional information, in the eye imaginal disc of Drosophila. Cell 51: 143-150.

Tomlinson, A., B.E. Kimmel, and G.M. Rubin. 1988. rough, a Drosophila homeobox gene required in photoreceptors R2 and R5 for inductive interactions in the developing eye. Cell 55: $771-784$

Turner, D.L. and C.L. Cepko. 1987. A common progenitor for neurons and glia persists in rat retina late in development. Nature 328: $131-136$.

Vinson, C.R. and P.N. Adler. 1987. Directional non-cell autonomy and the transmission of polarity information by frizzled gene and Drosophila. Nature 329: 549-551.

Vinson, C.R., S. Conover, and P.N. Adler. 1989. A Drosophila tissue polarity locus encodes a protein containing seven potential transmembrane domains. Nature 338: 263-264.

von Heijne, G. 1983. Patterns of amino acids near signal-sequence cleavage sites. Eur. $J$. Biochem. 133: 17-21. 


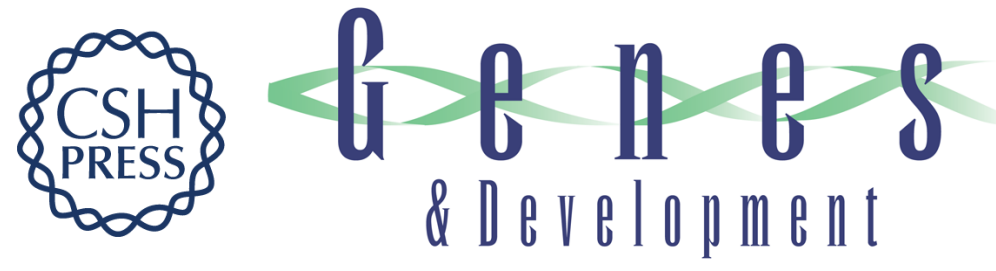

\section{Induction of cell fate in the Drosophila retina: the bride of sevenless protein is predicted to contain a large extracellular domain and seven transmembrane segments.}

A C Hart, H Krämer, D L Van Vactor, et al.

Genes Dev. 1990, 4:

Access the most recent version at doi:10.1101/gad.4.11.1835

References This article cites 78 articles, 22 of which can be accessed free at:

http://genesdev.cshlp.org/content/4/11/1835.full.html\#ref-list-1

License

Email Alerting

Service

Receive free email alerts when new articles cite this article - sign up in the box at the top right corner of the article or click here.

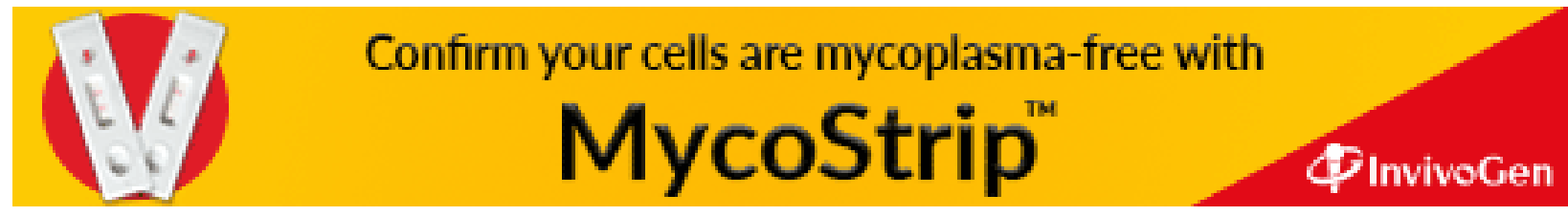

